\title{
Acute and Subacute Toxic Aqueous Extract of the Leaves of Petroselinum Crispum Mill. in Male and Female Wistar Rats
}

\author{
Kablan Kassi Jean Jacques, \\ University Felix Houphouët-Boigny, Abidjan, Ivory Coast, UFR \\ Biosciences, Laboratory of Biology and Health \\ Blahi Adelaïde Nadia, \\ University Jean Lorougnon Guédé Daloa, Ivory Coast, UFR Environment, \\ Biodiversity and Tropical Ecology Laboratory \\ Kouakou Koffi Roger, \\ Diby Yao Seraphin, \\ Siapo Yao Martin, \\ Tahiri Annick, \\ University Felix Houphouët-Boigny, Abidjan, Ivory Coast, UFR \\ Biosciences, Laboratory of Biology and Health
}

Doi:10.19044/esj.2021.v17n40p178

Submitted: 10 September 2021

Accepted: 04 October 2021

Published: 30 November 2021
Copyright 2021 Author(s)

Under Creative Commons BY-NC-ND 4.0 OPEN ACCESS

Cite As:

Jacques K.K.J., Nadia B.A, Roger K.K., Seraphin D.Y.,Martin S.Y., \& Annick T.,(2021). Acute and Subacute Toxic Aqueous Extract of the Leaves of Petroselinum Crispum Mill. in Male and Female Wistar Rats. European Scientific Journal, ESJ, 17(40), 178.

https://doi.org/10.19044/esj.2021.v17n40p178

\section{Abstract}

The present study is part of a vast program of the valorization of the medicinal flora and to help the populations to make a real profit from the use of plants in order to avoid any problem of poisoning. Petroselinum crispum Mill. (Apiaceae) is a plant, whose therapeutic virtues are diverse. The toxicological aspect of the aqueous extract of Petroselinum crispum leaves in male and female rats was investigated. The acute toxicity study with the single dose of $5000 \mathrm{mg} / \mathrm{Kg}$ body weight shows that the aqueous extract from the leaves of Petroselinum crispum is not toxic orally. According to Organisation for Economic Cooperation and Development (OECD) Guideline 423, the oral LD50 for this extract is greater than $5000 \mathrm{mg} / \mathrm{kg}$ body weight. In addition, the sub-acute toxicity study (OECD 407) showed that the aqueous extract from the leaves of Petroselinum crispum did not show any toxic effects at doses 50, 
100 and $200 \mathrm{mg} / \mathrm{kg}$ body weight and would have an orexigenic effect after 28 days of treatment. The different histological sections showed that the aqueous extract of Petroselinum crispum is not toxic on the vital organs and appears to be hepatoprotective.

Keywords: Petroselinum Crispum, Acute Toxicity, Subaigüe Toxicity, Histology, Rat

\section{Introduction}

Plants are an inexhaustible source of traditional remedies. These remedies are effective because of the active ingredients they develop (Sallé, 1991). Two-thirds of current drugs are of natural or hemi-synthetic origin and only one-third of marketed drugs are purely of synthetic origin (Newman \& Cragg, 2007). More than $80 \%$ of the African population mainly uses medicinal plants for treatment (OMS, 2002). Today, out of more than 300,000 plant species recorded worldwide, only about $15 \%$ have been studied phytochemically and $6 \%$ have biological activity (Verpoorte, 2002). Unfortunately, some plants in the pharmacopoeia can cause some severe poisoning. The severity of these poisonings depends on certain factors: the nature of the plant, the part consumed, the quantity, whether taken on an empty stomach or not, the age and the circumstances (Hafidi, 2014). In addition to its wide use as a green vegetable and garnish, $P$. crispum is used for different medicinal purposes in traditional medicine in different countries (Agyare et al., 2017). Petroselinum crispum is a plant used as a medicinal plant for gastrointestinal tract, kidney, lower urinary tract, and digestive stimulation (Blumenthal et al., 2000; Tucker \& DeBaggio, 2009). Seeds have been used in the treatment of gastrointestinal disorders, inflammation, kidney stones and amenorrhea, as well as carminative, astringent and gastrotonic in Iran (Behtash et al., 2008; Aghili et al., 2009). Its aerial parts are used for its high-dose abortive activities in Italy (Montesano et al., 2012). This high demand for $P$. crispum in traditional medicine and in various foods is the reason for this study, which aims to assess the toxicity of the aqueous extract of $P$. crispum leaves in male and female rats.

\section{Plant material}

The plant material used consists of fresh leaves of Petroselinum crispum (Apiaceae). The leaves are harvested in the south of Abidjan (Ivory Coast). A sample of this plant was deposited for authentication at the National Floristic Center of Ivory Coast. 


\section{Animal Material}

The animals used are male and female Rattus norvegicus (Muridae) rats of the Wistar strain. Rats are two to three months old and weigh between 100 and 140 grams. They were used to assess the acute and sub-acute toxicity of the aqueous extract from the leaves of Petroselinum crispum. These animals come from the Vivarium of the Normal High School (NHS) of Ivory Coast. The rats were fed ad libitum. The food consists of FACI ${ }^{\circledR}$, corn, bread and dry fish pellets. They were caged and acclimatized to a temperature of 25 to $28^{\circ} \mathrm{C}$. Their drink consisted exclusively of pump water.

\section{Methodology}

\section{Preparation of the aqueous extract}

The harvested fresh leaves are dried out from the sun at room temperature $\left(30 \pm 2{ }^{\circ} \mathrm{C}\right)$ and then crushed using an IAMAG-RCT ${ }^{\circledR}$ type electric grinder to obtain a powder. The resulting powder is macerated by mixing $50 \mathrm{~g}$ in 1.5 litres of distilled water. The whole is stirred for three times three minutes in a mixer of brand Single (Singapore). The macerate obtained is filtered four times on poplin fabric and then four times on hydrophilic cotton (Zirihi et al., 2003). The filtrate is evaporated in the oven at $50{ }^{\circ} \mathrm{C}$ for 48 hours. A dry aqueous extract of Petroselinum crispum (EAPC) of brown color is obtained and was used to carry out the various tests.

\section{Acute oral toxicity}

Acute oral toxicity was conducted according to OECD Guideline 423. It is intended to assess the acute toxicity of Petroselinum crispum aqueous extract by gavage. It can be achieved by focusing on the different clinical signs of toxicities (coma, convulsion, lethargy, salivation) and possible deaths. Thus, nine female rats, nulliparous, aged from eight to twelve weeks whose mass is between 120-140 g were deprived of food for 14 hours before treatment. Thus, after the fasting period, the animals are individually marked and weighed. They are divided into three lots of three rattes, including one control lot and two treated lots. The control lot was treated with distilled water, while the treated lots received the single doses of $5000 \mathrm{mg} / \mathrm{kg}$ bw by stages of the aqueous extract from the leaves of $P$. crispum. The animals were then observed individually for the first 30 minutes and regularly for the first 24 hours after treatment. Four hours after treatment, animals have free access to food and are observed again every 24 hours for 14 days (Ogbonnia et al., 2008). During treatment, the animals were weighed every two days at the same time. 


\section{Subacute oral toxicity}

Sub-acute toxicity was achieved by gavage in rats according to OECD Guideline 407 (OCDE, 2008). Rats were 8-10 weeks old with a mass interval of 100-140 g. Rats were divided into two groups of 20 rats by sex. Each group consisted of four lots, including five rats per lot. Lot 1 of each group received $1 \mathrm{ml} / 100 \mathrm{~g}$ of the body weight of distilled water. Batches 2,3 and 4 received increasing daily doses of the total aqueous extract from $P$. crispum leaves of 50, 100 and $200 \mathrm{mg} / \mathrm{kg}$ bw, respectively, for 28 days. The behaviour of the animals is observed daily during and after treatment and their mass is taken every two days. At the end of the treatment, the animals were killed by decapitation after anesthesia with ether. The blood of each animal was collected in both dry tubes without anticoagulant and in tubes containing anticoagulant (EDTA= Ethylenediamine tetracetic) respectively for the determination of biochemical and hematologic parameters. Then vital organs such as the kidney, liver, heart and lung were collected and weighed and stored in $10 \%$ formalin for histopathological studies (Rhiouani et al., 2008). The relative mass of the organs is determined by the following formula:

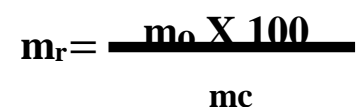

mr: relative mass (g/100 g); mo: organ mass in g; mc: rat body mass in g

\section{Biochemical parameters}

The blood samples taken from the tubes without anticoagulant were centrifuged at $4000 \mathrm{rpm}$ for 10 minutes using a centrifuge (LC-04B PLUS German). The serums were aliquoted in Eppendorfs tubes and kept in the freezer $\left(-20^{\circ} \mathrm{C}\right)$ to determine the various biochemical parameters. Several methods made it possible to measure the parameters sought according to their specificities. Alanine aminotransferase (ALAT), Aspartate aminotransferase (ASAT) and creatinine were performed using the kinetic method (Cheesbrough, 1991). Bilirubin was determined by the calorimetric method (Tietz, 2006). Thus urea, uric acid and lipids such as triglycerides, cholesterol and HDL were determined by the enzymatic test (Allain et al., 1974). All these dosages were made by an automaton of type Rayto RT-9200, China.

\section{Hematological parameters}

Blood samples from anticoagulant-containing tubes (EDTA) were directly used to determine white blood cell, red blood cell, hemoglobin, hematocrit, average hemoglobin concentration, Blood platelets and mean platelet volume according to standard methods using an automaton (SYSMEX-KX-21N; Greece) (Jain, 1986). 


\section{Histopathological study}

The histopathological study of vital organs was carried out to detect possible toxic effects induced by Petroselinum crispum extract at microscopic dimensions on the structure of these organs (Zougrou, 2017). Organs previously preserved in $10 \%$ formalin for 48 hours were cut using a microtome after inclusion in paraffin. The organs were then stained with hematoxylineosin, fixed between the blade and the lamella with Eukitt before being observed using a photonic microscope (Olympus CK41 SF, Philippine) connected to a computer. The shooting and analysis of the images were done thanks to the software AmScope MD130 versions 3.7 (France). The various magnifications made it possible to assess the possible tissue abnormalities of the organs.

\section{Statistical Analysis}

Statistical analyses of the experimental results were performed using GraphPad Prism 7.1 software (Microsoft, USA). The values are presented as a standard mean error on the mean. The data were evaluated using the oneway ANOVA analysis method followed by the Tukey multiple comparison test at the $5 \%$ threshold to assess the significance of the differences observed. If $\mathrm{p}<0.05$ the difference between the values is considered significant. In addition, the graphical representations were made using the same software.

\section{Results}

\section{Acute oral toxicity}

The study of acute toxicity at a dose of $5000 \mathrm{mg} / \mathrm{Kg}$ body weight of the aqueous extract from the leaves of $P$. crispum does not cause a significant change after 14 days on the body mass of the rattes after treatment compared to the mass of the controls (Table I). Examination of the clinical signs of toxicity during the observation period did not reveal any change in treated rattes compared to controls (Table II). The vital organs including the kidney, liver, lung and heart collected and weighed after treatment showed no significant difference $(\mathrm{p}>0.05)$ between control and treated rattes at 5000 $\mathrm{mg} / \mathrm{Kg}$ body weight (Table III). According to the Globally Harmonized Classification and Labelling System (GHS), the lethal dose for 50 \% (LD50) would be greater than $5000 \mathrm{mg} / \mathrm{Kg}$ body weight. 
Table I: Effects of aqueous extract of petroselinum crispum leaves on body weight in female rats after 14 days of treatment

Group

Treatments body weight

Before treatment (j0) After treatment (j14)
$\mathbf{R}$

Mean \pm ESM

$170.9 \pm 5.12$

$171.3 \pm 3.53$ ns

ns

Treated (5000 mg/kg bw)

$144.4 \pm 4.74$

Values are averages \pm ESM $($ ESM= Standard Error on the Mean); ns = not significant at $p>0.05$; bw: body weight; $R$ : note

Table II: Clinical Signs of female rats after 14 days at $5000 \mathrm{mg} / \mathrm{Kg}$ bw

\begin{tabular}{|c|c|c|c|c|c|c|c|c|c|c|c|c|}
\hline \multirow[b]{2}{*}{ Observation } & \multicolumn{2}{|c|}{$30 \mathrm{~min}$} & & \multirow{2}{*}{$\begin{array}{c}\mathbf{4 h} \\
\mathrm{C} \\
\mathrm{T}\end{array}$} & \multicolumn{2}{|c|}{$24 h$} & \multicolumn{2}{|c|}{$48 \mathrm{~h}$} & \multicolumn{2}{|c|}{ 1Week } & \multicolumn{2}{|c|}{2 Weeks } \\
\hline & $\mathrm{C}$ & $\mathrm{T}$ & & & $\mathrm{C}$ & $\mathrm{T}$ & $\mathrm{C}$ & $\mathrm{T}$ & $\mathrm{C}$ & $\mathrm{T}$ & $\mathrm{C}$ & $\mathrm{T}$ \\
\hline Fur & & & & $\begin{array}{l}\mathrm{N} \\
\mathrm{N}\end{array}$ & $\mathrm{N}$ & $\mathrm{N}$ & & & $\mathrm{N}$ & $\mathrm{N}$ & $\mathrm{N}$ & $\mathrm{N}$ \\
\hline Eyes & & & & $\begin{array}{l}\mathrm{N} \\
\mathrm{N}\end{array}$ & $\mathrm{N}$ & $\mathrm{N}$ & & & $\mathrm{N}$ & $\mathrm{N}$ & $\mathrm{N}$ & $\mathrm{N}$ \\
\hline Mucosa & & & & $\begin{array}{l}\mathrm{N} \\
\mathrm{N}\end{array}$ & $\mathrm{N}$ & $\mathrm{N}$ & & & $\mathrm{N}$ & $\mathrm{N}$ & $\mathrm{N}$ & $\mathrm{N}$ \\
\hline Salivation & - & - & & - & - & - & - & - & - & - & - & - \\
\hline Lethargy & - & - & & - & - & - & - & - & - & - & - & - \\
\hline Sleep & $\mathrm{N}$ & $\mathrm{N}$ & & $\begin{array}{l}\mathrm{N} \\
\mathrm{N}\end{array}$ & $\mathrm{N}$ & $\mathrm{N}$ & $\mathrm{N}$ & $\mathrm{N}$ & $\mathrm{N}$ & $\mathrm{N}$ & $\mathrm{N}$ & $\mathrm{N}$ \\
\hline Coma & - & - & - & & - & - & - & - & - & - & - & - \\
\hline Convulsion & - & - & - & & - & - & - & - & - & - & - & - \\
\hline Earthquake & - & - & - & & - & - & - & - & - & - & - & - \\
\hline Diarrhea & - & - & - & & - & - & - & - & - & - & - & - \\
\hline Morbidity & - & - & - & & - & - & - & - & - & - & - & - \\
\hline Mortali & - & - & - & & - & - & - & - & - & - & - & - \\
\hline
\end{tabular}

Table III: Effects of aqueous extract of petroselinum crispum leaves on the relative mass of vital organs of female rats

\begin{tabular}{|c|c|c|c|c|c|}
\hline \multirow{2}{*}{$\begin{array}{c}\text { Treatments of } \\
\text { Animals (mg/kg } \\
\text { bw) }\end{array}$} & \multirow{2}{*}{$\begin{array}{l}\text { Number } \\
\text { of rattes }\end{array}$} & \multicolumn{4}{|c|}{ Organ removed (g/100g body weight ) } \\
\hline & & Kidney & Liver & Lung & Heart \\
\hline Controls & 3 & $0.639 \pm 0.01$ & $\begin{array}{c}3.716 \pm \\
0.13\end{array}$ & $\begin{array}{c}0.735 \pm \\
0.11\end{array}$ & $\begin{array}{c}0.433 \pm \\
0.03\end{array}$ \\
\hline Treated & 3 & $0.623 \pm 0.02$ & $3.76 \pm 0.11$ & $\begin{array}{c}0.744 \pm \\
0.08\end{array}$ & $\begin{array}{c}0.430 \pm \\
0.04\end{array}$ \\
\hline
\end{tabular}


$5000 \mathrm{mg} / \mathrm{Kg}$

body weight

The values are averages \pm ESM (ESM=Standard Error on the Mean); bw: body weight; the sense of reading is the vertical direction; the values are not significant at $p>0.05$

\section{Subacute oral toxicity}

\section{Toxicity body weight gain (bw)}

Changes in body masses in male and female rats treated daily for 28 days at different doses of aqueous extracts from Petroselinum crispum leaves gradually increase with that of the control. The gains in final body masses at doses 50,100 and $200 \mathrm{mg} / \mathrm{kg}$ bw of the aqueous extract from $P$. crispum leaves were $65.14 \pm 1.213 ; 57.72 \pm 1.257 ; 46.83 \pm 0.961 \%$ in treated male rats, respectively. These values are significantly higher than the control values of $42.32 \pm 0.65 \%$ (Figure 1). For female rats, these values were $26.37 \pm 0.69$; $24.92 \pm 0.61 ; 23.41 \pm 0.60 \%$ compared to $20.30 \pm 0.66 \%$ for controls (Figure 2 ). The aqueous extract from the leaves of $P$. crispum induced a significant increase in body weight in male and female rats compared to the control.

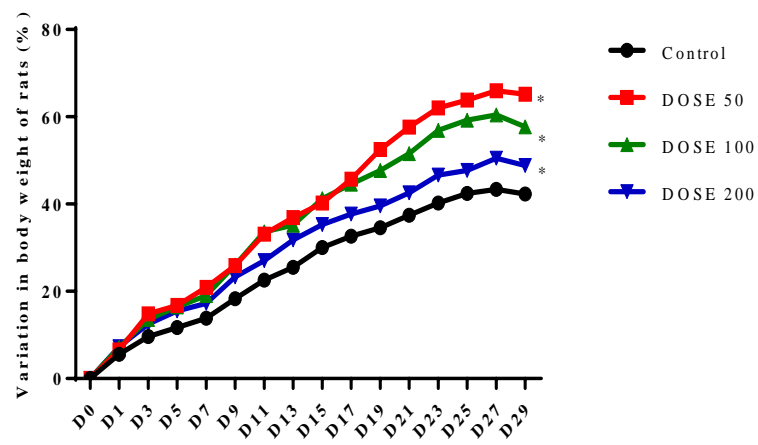

Picture 1: Change in body weight of male rats over 28 days of daily treatment with aqueous extract of Petroselinum crispum leaves. D: days

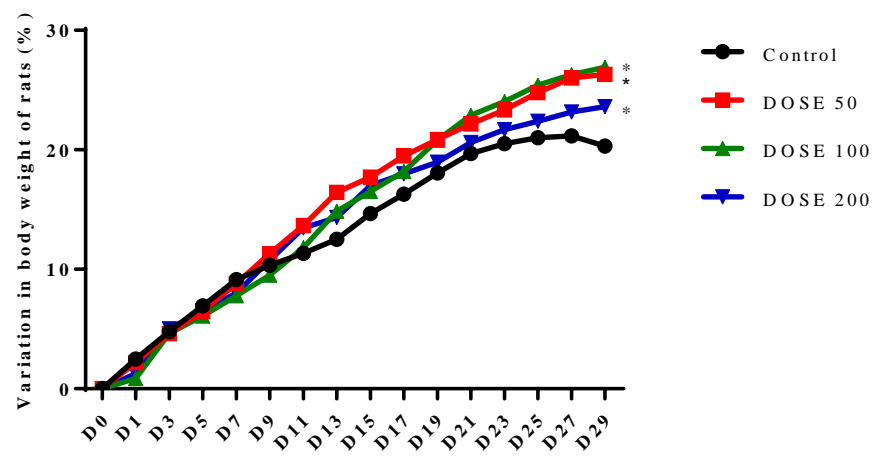

Picture 2: Variation in body weight of female rats over 28 days of daily treatment with aqueous extract of Petroselinum crispum leaves. D: days 


\section{Change in relative organ mass}

The relative organ masses of male and female rats collected at the end of treatment at doses of 50,100 and $200 \mathrm{mg} / \mathrm{Kg}$ of body weight did not change significantly $(\mathrm{p}>0.05)$ compared to controls over the 28-day period (Table IV and V).

Table IV: Effect of the aqueous extract from the leaves of Petroselinum crispum on the vital organs of male rats after 28 days of daily treatment

\begin{tabular}{ccccc}
\hline \multicolumn{5}{c}{ Treatment of animals in $\mathbf{~ m g} / \mathbf{k g}$ body weight } \\
\hline Organs in g/100 g & Controls & Dose 50 & Dose 100 & Dose 200 \\
Heart & $0.363 \pm 0.01$ & $0.335 \pm 0.01$ & $0.323 \pm 0.008$ & $0.323 \pm 0.01$ \\
Lung & $0.776 \pm 0.01$ & $0.763 \pm 0.06$ & $0.747 \pm 0.02$ & $0.750 \pm 0.07$ \\
Liver & $2.503 \pm 0.09$ & $2.518 \pm 0.09$ & $2.518 \pm 0.03$ & $2.383 \pm 0.06$ \\
Kidney & $0.53 \pm 0.01$ & $0.52 \pm 0.02$ & $0.51 \pm 0.01$ & $0.5 \pm 0.01$ \\
\hline
\end{tabular}

Values are averages \pm ESM (ESM= Standard Error on the Mean); Horizontal Reading

Table V: Effect of the aqueous extract from the leaves of Petroselinum crispum on the vital organs of female rats after 28 days of daily treatment

Treatment of animals in $\mathrm{mg} / \mathrm{kg}$ body weight

\begin{tabular}{ccccc}
\hline $\begin{array}{c}\text { Organs in } \\
\text { g/100g }\end{array}$ & Controls & Dose 50 & Dose 100 & Dose 200 \\
Heart & $0.322 \pm 0.01$ & $0.368 \pm 0.01$ & $0.372 \pm 0.01$ & $0.362 \pm 0.01$ \\
Lung & $0.802 \pm 0.04$ & $0.788 \pm 0.04$ & $0.778 \pm 0.03$ & $0.748 \pm 0.04$ \\
Liver & $2.492 \pm 0.03$ & $2.380 \pm 0.04$ & $2.463 \pm 0.04$ & $2.306 \pm 0.06$ \\
Kidney & $0.487 \pm 0.01$ & $0.477 \pm 0.01$ & $0.467 \pm 0.01$ & $0.480 \pm 0.01$ \\
\hline
\end{tabular}

Values are averages \pm ESM (ESM= Standard Error on the Mean); Horizontal Reading

\section{Effect of Petroselinum crispum extract on biochemical and hematological parameters after 28 days of daily treatment \\ Male rats}

In males, the aqueous extract of Petroselinum crispum induced no significant change $(p>0.05)$ in the concentration of urea, creatinine, uric acid, and the amount of ASAT and then ALAT at 50, 100, and $200 \mathrm{mg} / \mathrm{kg}$ body weight. However, the total extract of $P$. crispum induced a non-significant decrease $(p>0.05)$ at these same doses at bilirubin concentration. But, results in a significant increase $(\mathrm{p}<0.0 .1)$ of total protein compared to the control (Table VI).

Table VI: Effect of Petroselinum crispum extract on biochemical parameters in male rats after 28 days of daily treatment

\section{Treatment of animals in $\mathrm{mg} / \mathrm{kg}$ body weight}

\begin{tabular}{lllll}
\hline $\begin{array}{l}\text { Biochemical } \\
\text { parameters }\end{array}$ & Controls & Dose 50 & Dose 100 & Dose 200
\end{tabular}




\begin{tabular}{lllll}
\hline Uric acid & $3.00 \pm 0.408$ & $3.00 \pm 0.408$ & $2.75 \pm 0.478$ & $2.52 \pm 0.500$ \\
Creatinine & $0.99 \pm 0,05$ & $0.98 \pm 0.038$ & $0.95 \pm 0.052$ & $0.99 \pm 0.056$ \\
Bilirubin & $0.26 \pm 0.410$ & $0.25 \pm 0.036$ & $0.24 \pm 0.029$ & $0.24 \pm 0.034$ \\
Urea & $0.17 \pm 0.010$ & $0.17 \pm 0.011$ & $0.18 \pm 0.014$ & $0.18 \pm 0.010$ \\
Total protein & $26.33 \pm 0.880$ & $33.5 \pm 0.866^{* *}$ & $33.33 \pm 1.850^{* *}$ & $31.75 \pm 0.850^{* *}$ \\
ASAT & $231.30 \pm 7.750$ & $231.30 \pm 11.160$ & $227.30 \pm 7.430$ & $223.00 \pm 8.826$ \\
ALAT & $43.67 \pm 2.186$ & $42.00 \pm 2.160$ & $41.75 \pm 2.490$ & $41.25 \pm 2.930$ \\
\hline
\end{tabular}

The values are averages \pm ESM (ESM= Standard Error on the Mean); Horizontal reading; $* *$ indicates that $(\mathbf{p}<0.01)$

Hematological analysis showed a very significant increase $(\mathrm{p}<0.001)$ in white blood cells and lymphocytes at 100 and $200 \mathrm{mg} / \mathrm{kg}$ body weight compared to the control. The aqueous extract of $P$. crispum induced a very significant increase in red blood cells and hematocrits at doses of 50, 100 and $200 \mathrm{mg} / \mathrm{Kg}$ body weight. The amount of hemoglobin also increased significantly at all doses 50, 100 and $200 \mathrm{mg} / \mathrm{kg}$ body weight compared to the control. No significant change in the number of plates was observed (Table VII).

Table VII: Effect of Petroselinum crispum leaf extract on hematologic parameters in male rats after 28 days of daily treatment

Treatment of animals in $\mathrm{mg} / \mathrm{kg}$ body weight

\begin{tabular}{ccccc}
\hline $\begin{array}{c}\text { Hematologic } \\
\text { parameters }\end{array}$ & Controls & Dose 50 & Dose 100 & Dose 200 \\
$\begin{array}{c}\text { Red blood cell } \\
\left(\times 10^{6} \mu \mathrm{L}^{-1}\right)\end{array}$ & $2.09 \pm 0.269$ & $5.73 \pm 0.138^{* *}$ & $6.298 \pm 0.234^{* *}$ & $6.868 \pm 0.443^{* *}$ \\
\hline $\begin{array}{c}\text { Hematocrit }(\%) \\
\text { Lymphocyte } \\
\left(\times 10^{3} \mu \mathrm{L}^{-1}\right)\end{array}$ & $20.17 \pm 0.88$ & $36.88 \pm 1.489^{* * *}$ & $37.33 \pm 0.44^{* * *}$ & $39.15 \pm 1.09^{* * *}$ \\
$\begin{array}{c}\text { Plate } \\
\left(\times 10^{3} \mu \mathrm{L}^{-1}\right)\end{array}$ & $815.3 \pm 98.33$ & $823.8 \pm 79.36$ & $809.3 \pm 42.88$ & $860.3 \pm 96.89$ \\
\hline $\begin{array}{c}\text { White blood cell } \\
\left(\times 10^{3} \mu \mathrm{L}^{-1}\right)\end{array}$ & $8.068 \pm 1.26$ & $8.52 \pm 1.112$ & $12.32 \pm 0.61^{* *}$ & $12.37 \pm 1.12^{* *}$ \\
\hline Hemoglobin $(\mathrm{g} / \mathrm{dL})$ & $11.25 \pm 0.16$ & $13.18 \pm 0.18^{*}$ & $13.01 \pm 0.24^{*}$ & $13.08 \pm 0.11^{*}$ \\
\hline
\end{tabular}

The values are ESM averages (ESM= Standard Error on the Mean); Horizontal reading

*indicates that $(\mathrm{p}<0.05) * *$ indicates that $(\mathrm{p}<0.01)$; *** indicates that $(\mathrm{p}<0.001)$.

\section{Female rats}

Treatment of female rats with Petroselinum crispum aqueous extract at doses 50, 100 and $200 \mathrm{mg} / \mathrm{Kg}$ body weight does not result in a significant increase $(p>0.05)$ in parameters. However, there is a non-significant decrease $(p>0.05)$ in bilirubin, creatinine and serum ALAT concentration compared to the control. With respect to uric acid, urea and ASAT levels, the total aqueous extract of $P$. crispum did not cause any significant variation $(p>0.05)$ at three dose levels from the control. However, the extract causes a significant increase 
$(p<0.05)$ in total protein at the three doses compared to the protein of the female rattes controls (Table VIII).

Table VIII: Effect of Petroselinum crispum aqueous extract on biochemical parameters in female rats after 28 days of daily treatment

\begin{tabular}{ccccc}
\hline & \multicolumn{4}{c}{ Treatment of animals in mg/kg body weight } \\
\hline $\begin{array}{c}\text { Biochemical } \\
\text { parameters }\end{array}$ & Controls & Dose 50 & Dose 100 & Dose 200 \\
Uric acid & $3.20 \pm 0.37$ & $3.40 \pm 0.40$ & $3.20 \pm 0.30$ & $3.00 \pm 0.45$ \\
Bilirubin & $0.676 \pm 0.017$ & $0.655 \pm 0.098$ & $0.627 \pm 0.122$ & $0.614 \pm 0.138$ \\
Creatinine & $0.764 \pm 0.05$ & $0.620 \pm 0.04$ & $0.628 \pm 0.062$ & $0.642 \pm 0.069$ \\
Urea & $0.145 \pm 0.002$ & $0.144 \pm 0.005$ & $0.144 \pm 0.005$ & $0.142 \pm 0.003$ \\
Total protein & $40.00 \pm 1.080$ & $43.25 \pm 2.660^{*}$ & $45.75 \pm$ & $43.5 \pm 1.323^{*}$ \\
ASAT & $244.50 \pm 8.93$ & $227.00 \pm 5.508$ & $225.50 \pm$ & $222.00 \pm 6.597$ \\
ALAT & $36.50 \pm 2.901$ & $36.67 \pm 2.124$ & $36.00 \pm 1.57$ & $33.00 \pm 1.140$ \\
\hline
\end{tabular}

The values are averages \pm ESM $(\mathrm{ESM}=$ Standard Error on the Mean); Horizontal reading *indicates that $(\mathrm{p}<0.05)$

The hematological analysis did not cause any significant difference $(p>0.05)$ in the concentration of red blood cells, hematocrit and platelets. However, the number of hemoglobin increases significantly at doses of 50, 100 and 200 $\mathrm{mg} / \mathrm{Kg}$ body weight compared to controls. The aqueous extract from the leaves of $P$. crispum induced a significant increase $(p<0.05)$ in the number of white blood cells and lymphocytes at $50 \mathrm{mg} / \mathrm{kg}$ body weight compared to controls (Table IX).

Table IX: Effect of Petroselinum crispum aqueous extract on hematologic parameters in female rats after 28 days.

\section{Treatment of animals in $\mathrm{mg} / \mathrm{kg}$ body weight}

\begin{tabular}{|c|c|c|c|c|}
\hline $\begin{array}{c}\text { Hematologic } \\
\text { parameter }\end{array}$ & Controls & Dose 50 & Dose 100 & Dose 200 \\
\hline $\begin{array}{l}\text { Red blood cell } \\
\qquad\left(\times 10^{6} \mu \mathrm{L}^{-1}\right)\end{array}$ & $6.26 \pm 0.260$ & $6.27 \pm 0.395$ & $6.39 \pm 0.370$ & $6.52 \pm 0.402$ \\
\hline Hematocrit (\%) & $35.96 \pm 1.344$ & $35.63 \pm 0.513$ & $33.25 \pm 0.768$ & $33.68 \pm 1.371$ \\
\hline $\begin{array}{l}\text { Lymphocyte } \\
\left(\times 10^{3} \mu \mathrm{L}^{-1}\right)\end{array}$ & $8.98 \pm 0.299$ & $11.78 \pm 0.532 *$ & $8.68 \pm 0.968$ & $8.88 \pm 0.489$ \\
\hline $\begin{array}{c}\text { Plate } \\
\left(\times 10^{3} \mu \mathrm{L}^{-1}\right)\end{array}$ & $542.20 \pm 58,830$ & $601.60 \pm 50.970$ & $629.60 \pm 61.780$ & $630.30 \pm 51.530$ \\
\hline $\begin{array}{l}\text { White blood cell } \\
\qquad\left(\times 10^{3} \mu \mathrm{L}^{-1}\right)\end{array}$ & $11.52 \pm 0.570$ & $14.40 \pm 0.54^{*}$ & $11.56 \pm 0.904$ & $11.50 \pm 0.635$ \\
\hline Hemoglobin (g/dl) & $11.96 \pm 0.37$ & $13.10 \pm 0.310^{*}$ & $13.48 \pm 0,390 *$ & $13.25 \pm 0.350 *$ \\
\hline
\end{tabular}

The values are ESM averages (ESM= Standard Error on the Mean); Horizontal reading *indicates that $(\mathrm{p}<0.05)$ 
Histopathological study of Kidney and liver showed no evidence of liver cell necrosis, inflammation or structural abnormality and apoptosis in rats treated with different doses of aqueous extracts of $P$. crispum leaves compared to the control.

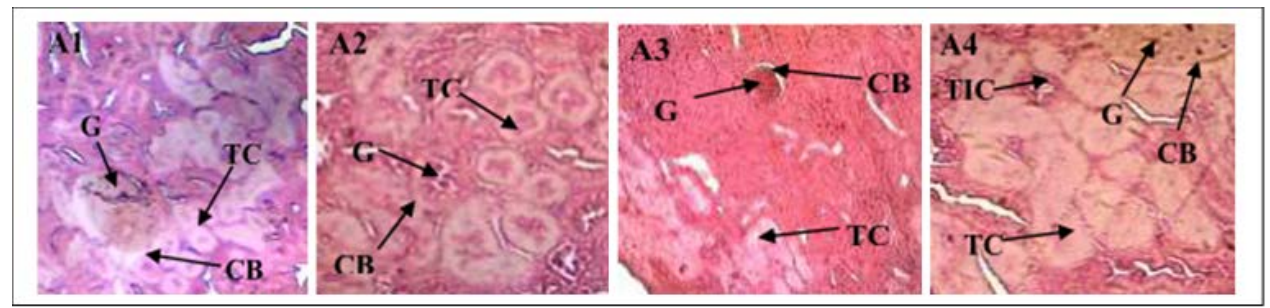

Picture 3: Histological section of the rat kidney in the sub-acute toxicity study Colouring: Hematoxylin and Eosin; G x 100

1: Control; A2: Treated at $200 \mathrm{mg} / \mathrm{Kg}$ of bw; A3: Treated at $100 \mathrm{mg} / \mathrm{Kg}$ of bw; A4: Treated at $50 \mathrm{mg} / \mathrm{Kg}$ of bw; G: Glomerulus; CB: Bowman capsule; TC: Contoured tube; TIC: Conjunctival-vascular interstitial tissue

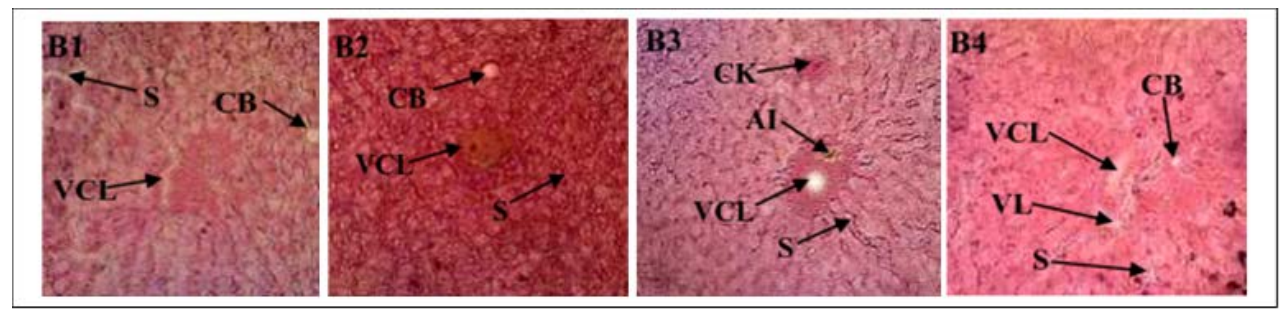

Picture 4: Histological section of the liver of rats in the sub-acute toxicity study Colouring: Hematoxylin and Eosin; G x 100

B1: Control; B2: Treated at $200 \mathrm{mg} / \mathrm{Kg}$ of bw; B3: Treated at $100 \mathrm{mg} / \mathrm{Kg}$ of bw; B4: Treated at $50 \mathrm{mg} / \mathrm{Kg}$ of bw; CK: Kupffer Cell; VCL: Central Lobular Vein; S: Sinusoid; CB: Bile Duct; AI: Inter-lobular Artery; VL: Lymphatic Vein

\section{Discussion}

The acute oral toxicity study of the aqueous extract from the leaves of $P$. crispum consisted of measuring and recording the various adverse effects that occurred after administration of the single dose of $5000 \mathrm{mg} / \mathrm{kg} \mathrm{bw}$. At this dose, there were no changes in behaviour, no signs of intoxication or mortality. This toxicity is based on the LD50 value, which is the lethal dose for $50 \%$ of the animal population tested to die. It is expressed as a mass of substance per animal body mass. This acute toxicity study showed that this plant is not toxic according to OECD 423. The LD50 is estimated to exceed $5000 \mathrm{mg} / \mathrm{kg}$ bw orally, which would explain the high consumption of this plant by the world population and particularly Ivorian. Indeed, this plant enters into the medicinal recipes and the dishes of African and European origin. Some work has shown that the aqueous extract of $M$. oleifera was not toxic at a dose of $2000 \mathrm{mg} / \mathrm{kg}$ bw (Kouakou \& Tahiri, 2018). Treatment of rats with Amaranthus viridis aqueous extract showed an LD50 greater than $5000 \mathrm{mg} / \mathrm{kg}$ bw (Affy et al., 
2018). However, showed that the ethanolic extract of Tridex procumbens showed clinical signs of toxicity (drowsiness, coma and morbidity) in rats 30 minutes after administration of the extract at $2000 \mathrm{mg} / \mathrm{kg}$ bw (Abrar et al., 2013). The toxicity of a substance in the literature varies with the route of administration. Substances with an LD50 greater than $5000 \mathrm{mg} / \mathrm{kg}$ bw are nontoxic (OCDE, 2001). According to GHS, the aqueous extract of P. crispum leaves would be in category 5 or not classified.

The results of the sub-acute toxicity study, which consists of giving repeated doses daily for 28 days by the oral route, showed a significant increase in body mass of treated animals over time compared to controls regardless of dose and sex. This increase in body mass could be linked to an increase in the appetite of animals by the aqueous extract of $P$. crispum, which would result in an increase in food consumption. This appetite stimulation is due to the presence of phenolic compounds that have the power to tone the stomach, improve its function and increase its appetite (Yanardag et al., 2003). Other authors, reported similar results in rats treated with the aqueous extract of Passiflora foetida and Senna alata for 28 days, respectively (Pieme et al., 2006). However, the work showed a reduction in body weight by administration of M. oleifera leaf extract (Sule \& Arhoghro, 2016).

The relative mass of organs (heart, lung, kidney, liver) collected at the end of treatment did not show significant variation in rats. These results could be explained by the various pharmacological activities that $P$. crispum possesses, such as hepatoprotective and nephropotective agents, already demonstrated (Huijuan et al., 2014). This result is similar to that obtained when Passiflora foetida was administered to rats for 28 days (Bleu et al., 2011). The study of biochemical parameters of treated animals was carried out by the determination of some parameters. ALAT is a cytosolic enzyme secreted in liver cells and released in hepatic necrosis (Dufour et al., 2000). It is a liver-specific enzyme, important as an indicator of hepatotoxicity (AlHabori et al., 2002). ASAT is also an indicator of hepatocyte destruction. It is present in addition to the liver, in the heart, skeletal muscles, lungs and kidneys (Bleu, 2013). ASAT and ALAT levels increase when liver and other organs are damaged including liver necrosis, cirrhosis and hepatotoxicity of certain drugs. In this study, the amount of these two enzymes decreased in animals treated with the different doses. This decrease is not significant but decreases when doses increase. Our results show that the aqueous extract of $P$. crispum may have a hepatoprotective effect in animals. These data are consistent with those obtained by other authors which showed that the aqueous leaf extract of $P$. crispum had a significant hepatoprotective effect in diabetic rats (Allam et al., 2016). The similar results obtained with $M$. oleifera extract by showing that this plant can preserve the structural integrity of hepatocyte membranes (Fakurazi et al., 2008). The chemical composition of P. crispum could provide 
serious clues that could lead to the identification of the chemical compounds responsible for its effect on liver enzymes. This plant is rich in flavonoids which confers hepatoprotective effects (Chaves et al., 2011). The effect of this plant on the liver would therefore be due to the presence of flavonoids (Gadi et al., 2012). The concentration of creatinine uric acid and total bilirubin showed no significant variation in male and female rats compared to their respective controls. On the other hand, total serum protein concentration increased significantly $(\mathrm{p}<0.05)$ in male and female rats at 50, 100 and 200 $\mathrm{mg} / \mathrm{kg}$ body weight compared to control rat serum protein. Identical results on protein increase have already been obtained with the aqueous extract of $M$. oleifera in rats (Kouakou \& Tahiri, 2018). P. crispum leaves may contain essential amino acids such as that recommended by FAO, WHO and UN in the reference protein (Kouakou, 2019).

In this work, the effects of the aqueous extract of $P$. crispum on the blood count were evaluated through hematological analyses. Some endpoints remained non-significant $(\mathrm{p}>0.05)$ in male rats in addition to the concentration of red blood cells, hemoglobin's and hematocrits that increased significantly at the 50,100 and $200 \mathrm{mg} / \mathrm{kg}$ body weight compared to the control. At 100 and $200 \mathrm{mg} / \mathrm{kg}$ body weight, the white blood cell and lymphocyte concentration increases significantly $(\mathrm{p}<0.01)$. This analysis showed no significant $(p>0.05)$ changes in hemoglobin, platelet, hematocrit and red blood cell concentrations in treated female rats compared to the control. However, a significant variation in body weight at the $50 \mathrm{mg} / \mathrm{kg}$ dose of lymphocyte and white blood cell concentration compared to the control was observed. This increase could be explained by the immunomodulatory activity of $P$. crispum (Yousofi et al., 2012). Other authors found identical results by the use of aqueous extract from the leaves of Sarcocephalus latifolus (Blahi, 2017) and M. oleifera (Ajugwo et al., 2017).

The increase in the number of white blood cells and lymphocytes at the 50 -dose in females and 100 and $200 \mathrm{mg} / \mathrm{kg}$ body weight in males was also observed with essential oils extracted from $P$. crispum flowers by hydrodistillation (Marin et al., 2016). The author states that these effects may be linked to the anti-carcinogenic and antidiabetic effects when the extract is used in high doses. The absence of structural abnormalities, inflammation, hepatic cell necrosis and nothing and liver apoptosis in rats treated with aqueous leaf extract confirms the results of relative organ mass, biochemical and hematological parameters. In several animal studies showed that the consumption of Moringa oleifera positively influenced many neutrophils (Nfambi et al., 2015). 


\section{Conclusion}

The acute toxicity study with the single dose of $5000 \mathrm{mg} / \mathrm{kg}$ body weight of the aqueous extract of Petroselinum crispum shows that the aqueous extract from the leaves of Petroselinum crispum is not toxic orally. In addition, the oral administration of the various doses for 28 days revealed a gradual increase in the weight of the animals. The aqueous extract of Petroselinum crispum has a hepatoprotective, nephropotective effect on vital organs and an immunomodulatory effect. Petroselinum crispum is a useful and important medicinal plant with a wide range of medicinal activities. However, this stady must be further developed by carrying out clinical trials in humans with the agreement of the Ethics Commission with a specific protocol.

We certify that there is no conflict of interest between the authors.

\section{References:}

1. Abrar H.M., Manjusha S. \& Mohd Y.M., 2013. An acute oral toxicity study of methanolic extract from Tridex procumbens in Sprague Dawley's Rats as per OECD guidelines 423. Asian Journal of Plant Science and Research. 3(1):16-20.

2. Affy M.E., Blahi A.N., Coulibaly F.A. \& Kouakou K., 2018. Evaluation of acute and subacute toxicity induced by methanol extract of Amaranthus viridis (Amaranthaceae) leaves in wistar rats (Rattus norvegicus). Journal of the Pharma Innovation, 7(7): 625-630.

3. Aghili M.H., Makhzan-al-Advia R.R., \& Shams A.M.R., 2009. Farjadmand F, editors. Tehran: Tehran University of Medical Sciences, pp 329-330.

4. Agyare C., Appiah T., Boakye Y.D. \& Apenteng J.A., 2017. Petroselinum crispum: a review. In Medicinal spices and vegetables from Africa. Academic Press pp 527-547.

5. Ajugwo A.O., Nwoké B., Ozims S.J., Eberendu I. \& Nwibana B.K., 2017. Prevalence ofhbsag and haematological parameters among pregnant women attending a Nigerian tertiary hospital. Acta Scientific Nutritional health. 1(3): 55-60.

6. Al-Habori M., Al-Aghbari A., Al-Mamary M., \& Baker M., 2002. Toxicological evaluation of Catha edulis leaves: a long-term animal feeding experiment. Journal of ethnopharmacology, 83(3): 209-217.

7. Allam A.A., Maodaa S.N., Abo-eleneen R. \& Ajarem J., 2016. Protective Effect of Parsley Juice (Petroselinum crispum, Apiaceae) against Cadmium Deleterious Changes in the Developed Albino Mice Newborns ( Mus musculus ) Brain. Oxidative Medicine and Cellular Longevity, Article ID 2646840, 15p. 
8. Allain C.C., Poom L.S., Chan C.S., Richmonal W.S. \& Fu P.C., 1974. Enzymatic determination of total serum cholesterol. Clinical Chemistry, 20: 470-475.

9. Behtash N., Kargarzadeh F. \& Shafaroudi H., 2008. Analgesic effects of seed extract from Petroselinum crispum (Tagetes minuta) in animal models. Toxicology Letters, 180 (5), S127-S128.

10. Blahi A.N., 2017. Effets pharmacologiques de l'extrait aqueux de feuilles Sarcocephalus latifolus (Smith) sur le système reproducteur des rats. Thèse de Doctorat en Biosciences. Université Félix Houphouët-Boigny Abidjan (Côte d'Ivoire) 188p.

11. Bleu M.G., Kouakou K., Touré A. \& Traoré F., 2011. Étude de la toxicité aigüe et subchronique de l'extrait aqueux de Passiflora foetida Linn (Passifloraceae) chez les rats et souris. International. Journal of Biology. Chemistry. Science. 5(5): 1777-1789.

12. Bleu G.M., 2013. Etude phytochimique, toxicologique et pharmacologique de Passiflora foetida Linn. (Passifloraceae), une plante utilisée dans le traitement de l'infertilité féminine. Thèse de Doctorat, Université Félix Houphouët Boigny Cocody-Abidjan 188p.

13. Blumenthal M., Goldberg A., \& Brinckman J., 2000. Expanded Commission E Monographs, (Newton, Mass.: Integrative Medicine Communications). Herbal Medicine, pp. 218-20.

14. Chaves D.S.A., Frattani F.S., Assafim M., de Almeida A.P., Zingali R.B. \& Costa S.S., 2011. Phenolic Chemical Composition of Petroselinum crispum Extract and Its Effect on Haemostasis. Natural Product Communications 6 (7) 961-964

15. Cheesbrough M. (1981). Medical laboratory manual for tropical countries (Vol. 1). M. Cheesbrough, 14 Bevills Close, Doddington, Cambridgeshire, PE15 OTT, 519 pp

16. Dufour D.R., Lott J.A., Nolte F.S., Gretch D.R., Koff R.S. \& Seeff L.B., 2000. Diagnosis and monitoring of hepatic injury II. Recommandation for use of laboratory test in screening, diagnosis and monitoring. Journal of Clinical Chemistry, 46: 2050-2068.

17. Fakurazi S., Hiruszah I. \& Nanthini U., 2008. Moringa oleifera lam prevents acetaminophen liver injury through restoration of glutathione level. Food and chemical toxicology. 46:2611-2615.

18. Gadi D., Bnouham M., Aziz M., Ziyyat A., Legssyer A., Bruel A., Berrabah M., Legrand C., Fauvel-Lafeve F. \& Mekhfi H., 2012. Flavonoids purified from parsley inhibit human blood platelet aggregation and adhesion to collagen under flow. Journal of Complementary and Integrative Medicine, article 19. doi: 10.1515/1553-3840. 
19. Hafidi K., 2014. Intoxications par les plantes et les produits de la pharmacopée traditionnelle chez l'enfant. Mémoire de Doctorat de médecine, Faculté de sciences et pharmacie, Universite Sidi Mohammed Ben Abdellah, Fes, (Maroc) 124p.

20. Huijuan J., Awa W., Hanated M., Takahashid S., Saitoa K., Tanakab H., Tomitac M. \& Kato H., 2014. Multi-faceted integrated omics analysis revealed parsley (Petroselinum crispum) as a novel dietary intervention in dextran sodium sulphate induced colitic mice Journal of Functional Foods, 11: 438-448.

21. Jain N.C., 1986. Schalm's Veterinary haematology. $4^{\text {th }}$ ed., Lea and Febber, Philadelphia, USA, 1221 pages.

22. Kouakou K.R. \& Tahiri A., 2018. Phytochemical screening, acute and subacute toxicity of aqueous extract of Moringa oleifera (Moringaceae) Lam 1885 on rats wistar. Journal of Medicinal Plants, 6(3) : 96-102.

23. Kouakou K.R., 2019.Toxicité et effets pharmacologiques de l'extrait total aqueux des feuilles de Moringa olifera (Moringacées) LAM 1785 sur le système reproducteur et le tissu osseux d'un modèle animal : Rattus norvegicus (Muridées) Souche Wistar. Thèse de Doctorat, Université Félix Houphouët-Boigny Cocody-Abidjan. 187p

24. Marin I., Sayas-Barberá E., Viuda-Martos M., Navarro C. \& Sendra E., 2016. Chemical Composition, Antioxidant and Antimicrobial Activity of Essential Oils from Organic Fennel, Parsley, and Lavender from Spain. Foods, 1-10.

25. Montesano V., Negro D., Sarli G., De Lisi A., Laghetti G., \& Hammer K., 2012. Notes about the uses of plants by one of the last healers in the Basilicata Region (South Italy). Journal of Ethnobiology and Ethnomedicin, 8: 15

26. Newman D. \& Cragg G.M., 2007. Natural products as sources of new drugs over the last 25

27. years. Journal of Natural Product; 70: 461-477.

28. Nfambi J., Bbosa G.S., Sembajwe L.F., Gakunga J. \& Kasolo J.N., 2015. Immunomodulatory activity of methanolic leaf extract of Moringa oleifera in Wistar albino rats. Joural of Basic and Clinical Physiology and Pharmacology, 26(6): 603-611

29. Ogbonnia S., Adekunle A.A., Bosa M.K. \& Enwuru V.N., 2008. Evaluation of acute and subcute toxicity of Alstonia congensis Engler (Apocinaceae) bark and Xylopia aethiopica (Dunal) A. Rich (Annonaceae) fruits mixtures used in the treatment of diabetes. African. Journal Biotechnology, 7(6): 701-705 
30. OCDE, 2001. Ligne directrice de l'OCDE pour les essais de produits chimiques : Toxicité oraleaiguë - Méthode par classe de toxicité aiguë. OCDE 423.14p

31. OCDE, 2008. Étude de toxicité orale à dose répétée pendant 28 jours sur les rongeurs. In: ligne directrice de l'OCDE pour les essais de produits chimiques. 2008; $14 \mathrm{p}$.

32. OMS., 2002. Stategie de l'Organisation Mondiale de la Santé (OMS) pour la médecine

33. traditionnelle pour 2002-2005. WHO/EDM/TRM: 77 p

34. Pieme C.A., Penlap V.N., Nkegoum B., Taziebou C.I., Tekwu E.M., Etoa F.X. \& Ngongang J., 2006. Evaluation acute and subacute toxicities of aqueous ethanolic extract of leaves of senna alata (l.) Roxb (Ceasalpiniacéé). African Journal of Biotechnology, 5: 283-289.

35. Rhiouani H., El-hilaly J., Israili Z.H. \& Lyoussi B., 2008. Acute and subchronic toxicity of an aqueous extract of the leaves of herniaria glabra in rodents. Journal of Ethnopharmacology 118: 378-386.

36. Sallé J.L., 1991. " Le Totum en Phytothérapie " Approche de phytothérapie. Ed Frison-Roche. Paris 50p.

37. Sule O.J. \& Arhoghro E.M., 2016. Hypocholesterolemic and hypoglycaemic effects of ethanolic extract Of Leaf of Moringa oleifera Lam. in high fat diet fed Wistar rats, Journal of Medical and Biological Science Research 2(6):109-113.

38. Tietz N.W., 2006. Clinical guide to loboratory test W.B. Saunders company, $4^{\text {th }}$ edition, Philadelphia, USA, 1952 pages.

39. Tucker A.O. \& DeBaggio O., 2009. Encyclopedia of herbs. Timber Press. Portland,

40. Oregon. Pp 393-394.

41. Verpoorte R., 2002. La pharmacognosie du nouveau millénaire: pistes et biotechnologies. Des sources du savoir aux médicaments du futur, $4^{\circ}$ congrès européen d'ethnopharmacologie. IRD Edition, Paris, $274 \mathrm{p}$.

42. Yanardag R., Bolkent S., Tabakoglu-Oguz A. \& Ozsoy-Sacan O., 2003. Effects of Petroselinum crispum extract on pancreatic B cells and blood glucose of streptozotocin-induced diabetic rats. Biological and Pharmaceutical Bulletin, 26(8): 1206-1210.

43. Yousofi A., Daneshmandi S., Soleimani N., Bagheri K., \& Karimi M.H., 2012. Immunomodulatory effect of Parsley (Petroselinum crispum) essential oil on immune cells: mitogen-activated splenocytes and peritoneal macrophages. Immunopharmacology and Immunotoxicology, 34(2): 303-308.

44. Zirihi G.N., Kra A.M. \& Guédé-Guina F., 2003. Évaluation de l'activité antifongique de Microglossa pyrifolia (LAMARCK) O. KUNZE (ASTERACEAE) <<PYMI $>>$ sur la croissance in vitro de 
Candida albicans'. Revue de Medicinal of Pharmacology African. 17:11-18.

45. Zougrou N.E., 2017. Evaluation des effets toxicologiques et pharmacologiques d'un extrait

46. Aqueux de cnestis ferruginea vahl ex dc. (connaraceae) sur le système reproducteur des rats mâle et femelle. Thèse de Doctorat en Biosciences. Université Félix Houphouët-Boigny Abidjan, 226p. 